Article

\title{
Spatial Distribution of Estimated Wind-Power Royalties in West Texas
}

\author{
Christian Brannstrom *, Mary Tilton, Andrew Klein and Wendy Jepson \\ Department of Geography, Texas A\&M University, 810 O\&M Building, College Station, TX 77843, \\ USA; E-Mails: m.tilton83@gmail.com (M.T.); klein@geog.tamu.edu (A.K.); \\ wjepson@geos.tamu.edu (W.J.)
}

* Author to whom correspondence should be addressed; E-Mail: cbrannst@geos.tamu.edu; Tel.: +1-979-845-5923; Fax: +1-979-862-4487.

Academic Editors: Claudia A. Radel and Jacqueline M. Vadjunec

Received: 15 July 2015 / Accepted: 12 November 2015 / Published: 2 December 2015

\begin{abstract}
Wind-power development in the U.S. occurs primarily on private land, producing royalties for landowners through private contracts with wind-farm operators. Texas, the U.S. leader in wind-power production with well-documented support for wind power, has virtually all of its $\sim 12 \mathrm{GW}$ of wind capacity sited on private lands. Determining the spatial distribution of royalty payments from wind energy is a crucial first step to understanding how renewable power may alter land-based livelihoods of some landowners, and, as a result, possibly encourage land-use changes. We located $\sim 1700$ wind turbines $(\sim 2.7 \mathrm{GW})$ on 241 landholdings in Nolan and Taylor counties, Texas, a major wind-development region. We estimated total royalties to be $\sim \$ 11.5$ million per year, with mean annual royalty received per landowner per year of $\$ 47,879$ but with significant differences among quintiles and between two sub-regions. Unequal distribution of royalties results from land-tenure patterns established before wind-power development because of a "property advantage," defined as the pre-existing land-tenure patterns that benefit the fraction of rural landowners who receive wind turbines. A "royalty paradox" describes the observation that royalties flow to a small fraction of landowners even though support for wind power exceeds 70 percent.
\end{abstract}

Keywords: wind power; royalty; property; land use; income; Texas 


\section{Introduction}

Explaining how biofuels affect land change is a key research theme in hybrid land change science that aims to incorporate insights from political ecology [1], but linkages between land change and utility-scale renewable energy are poorly understood. The rapid expansion of wind-power development in the U.S., primarily on private landholdings in a region from Texas to Minnesota, has produced unknown outcomes for livelihoods and land uses through the production of royalties for landowners who make private contracts with wind-farm operators. In dozens of rural communities, wind power has produced obvious impacts on land cover from construction of wind turbines and maintenance roads; however, these plainly visible land changes contrast with far less visible effects on landowner livelihoods and land cover, which have multiple potential behavioral, financial, and environmental determinants.

More than 97 percent of the $\sim 60 \mathrm{GW}$ of installed wind power capacity in the U.S. has been built on private land [2,3]. With 12,214 MW of installed capacity, Texas is the leading U.S. state, where 10 percent of its electricity comes from wind farms - virtually all sited on private lands - in the state's western region [4]. Wind turbines represent a land use that farmers and ranchers view as compatible with livestock grazing, hunting, or agriculture, and social acceptance is high [5-7]. Knowledge of the spatial distribution of royalty payments from wind energy is a crucial first step to understanding how income from renewable power may alter land-based livelihoods and may encourage land-use changes.

Here we use GIS-based methods and a royalty formula to estimate the amount and spatial distribution of wind-power royalties in Nolan and Taylor counties (Figure 1), a core area of windfarms in Texas. We show that royalty distribution among landowners is unequal, especially between two sub-regions, because of pre-existing "property advantage." We also identify a "royalty paradox:" a tiny fraction of the overall rural population receives royalties, but over 70 percent of the population support wind power. Spatial patterns of royalties should inform studies of land change in areas of energy development and studies of livelihoods possibly altered by energy royalties. Studies of wind power support or opposition should consider the flow and distribution of financial resources to landowners when attempting to understand the social acceptance of wind power.

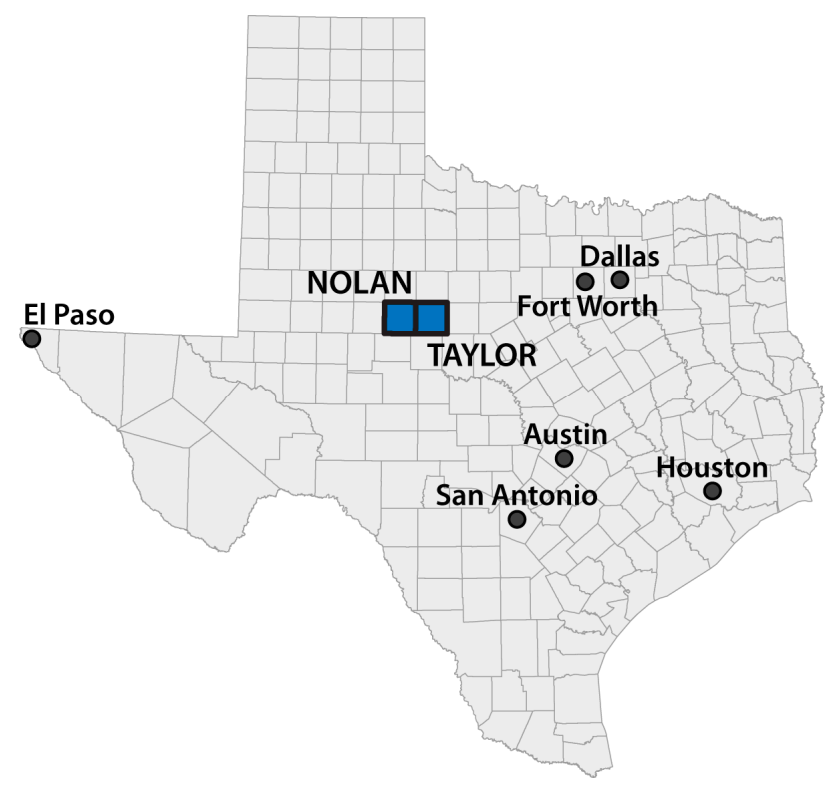

Figure 1. Nolan and Taylor Counties, Texas. 


\subsection{The Property Advantage}

One important spatial and land-based aspect of royalties is the "property advantage," which refers to unequal land-tenure patterns that may encourage unequal distribution of turbines and royalties. The distribution of royalties is important because it affects household wealth through increased land value [8]. More broadly, the spatial distribution of ownership of energy assets has attracted little critical attention, apart from recent work on shale gas in Denton, Texas [9]. Although Sowers included royalties into a "please-in-my-backyard" explanation for high apparent acceptance of wind power in rural Iowa [10], he did not estimate spatial distribution. Scholars of social, economic, and political aspects of wind-power expansion in North America have focused on other economic benefits, such as direct employment and indirect economic activity, arising from wind-power development, but livelihood implications are unknown.

More critical work reports possible tensions between landowners. In Ontario, Canada, wind turbines sited on private land generate income of at least $\$ 8000$ per year, but neighbors without turbines receive no compensation. Walker et al. [11] report that wealthy farmers were getting wealthier because of lease payments and other farmers argued that lease payments helped sustain their farm operations. One-third of respondents to their study agreed strongly with the claim that "residents living near wind turbines, but without one on their land should also receive financial benefits" ([11]; p. 738). This finding resonates with a warning that energy payments could "undermine social capital" in U.S. rural communities because so few landowners received income from energy ([8]; p. 22). The energy revenue stream is highly concentrated because of the small number of rural households that own land.

Royalty payments are absent from studies regarding community support or opposition to wind power. Swofford and Slattery [5] measured public attitudes to wind power near a $100 \mathrm{MW}$ wind farm in Texas, but their questionnaire did not prompt respondents to report whether they received royalties or lease payments. Abbott [12] found that public comments regarding wind farms in Washington state were positive with respect to impacts on agriculture, but it is not clear whether material benefits formed part of the view of wind power as "a new phase for extraction economies" ([12]; p. 981). Mulvaney et al. [13] reported that support for Indiana wind farms included the claim that turbines would help preserve farming or prevent farms from being turned into housing subdivisions, but they did not mention leases or royalties. Kahn [14] reported improvements in quality of life in places with wind farm development, specifically lower property taxes and increased school quality, but did not analyze royalty payments to landowners. Brown et al. [15] found an increase in county-level income and employment resulting from wind power, but did not indicate the specific impact of royalties and land leases on the estimated $\$ 11,000$ increase in annual personal income per MW of wind capacity installed.

One possible reason for the focus on economic and employment aspects is reliance on the Jobs and Economic Development Impacts (JEDI) model, developed by the National Renewable Energy Laboratory, which includes a measure of landowner lease payments between $\$ 3000$ and $\$ 7000$ per MW per turbine per year $($ default $=\$ 6000)$. Several research teams have relied on this input-output model to estimate direct employment in construction and operational phases and indirect economic activity [16,17]. Greene and Geisken [18] applied JEDI to a case in Oklahoma, estimating nearly $\$ 400,000$ in land lease payments for a $147 \mathrm{MW}$ wind farm, but they did not report the number of landowners affected in a county nor the spatial distribution of the wind turbines on properties. Indeed, JEDI estimates are not spatially explicit, focusing 
at county or state levels rather than on individual landowners. Moreover, lease payments are considered synonymous with royalties, while in practice, leases for roads and other infrastructure represent a separate revenue stream from royalties, which are based on variable electricity output per wind turbine and electricity price.

\subsection{The Royalty Paradox}

Following from the "property advantage" relating to land distribution is the broader social and political significance of royalties. We describe this as the "royalty paradox," which other scholars have suggested. For example, Slattery et al. [6] reported high social support for wind power in the west Texas and Iowa, with more than 70 percent of respondents to a mail-out survey indicating that wind energy improved employment and the overall economy. But they noted that, ironically, only "relatively few residents" ([6]; p. 3699) received direct benefits in the form of royalty income from wind power. Wind turbines were "seen as the vehicle that will reverse economic decline" plaguing many rural communities ([6]; p. 3699). Economic benefits, in terms of royalty payments, may help explain why people in some parts of the U.S. are highly supportive of wind power; however, we do not know how these payments are distributed spatially.

Financial aspects of the "royalty paradox" have been suggested by many journalists and wind-power promoters. Just as owners of mineral rights receive royalties based on the extraction of hydrocarbon resources, owners of surface land benefit from wind power generated from turbines sited on their land. Landowners with turbines receive royalties estimated at between $\$ 4000$ and $\$ 10,000$ per wind turbine sited on their land per year, depending upon electricity output and contract terms [19,20]. Sowers [10] reported that landowners in Iowa received between $\$ 2000$ and $\$ 2400$ per turbine per year under 30-year contracts for turbines ranging from 0.75-0.90 MW capacity. However, scholars have not yet examined royalties from wind-power generation in spatial detail. Weber et al. [8] report that approximately 8 percent of farms in the U.S. Plains received an energy payment for wind or natural gas. They concluded that energy payments on a national basis reached 3.4 percent of farms and totaled $\$ 2.3$ billion in 2011 compared to $\$ 11.8$ billion in annual government payments to farmers, although important spatial and temporal uncertainties persist.

More generally, financial benefits are part of community support for wind power in cases where public input is highly limited and large landowners have influence on siting decisions. Sharing or distributing financial benefits helps predict support for wind farms [11,21,22]. Bohn and Lant [23] predicted that "local investiture" and "local control over siting" wind-energy projects will lead to strong local and community support for wind power, but it was not clear whether "local investiture" includes royalty payments made to individual landowners ([23]; p. 97). This view echoed Pasqualetti's [24] prediction that support for wind will increase as economic returns and property values increase, but the specific influence of royalties in economic returns was not elaborated. Walker et al. [11] indicate that determining how financial benefits from wind farms are distributed should demand attention of researchers and policy makers.

The property advantage and royalty paradox represent new ways to analyze how utility-scale renewable energy may alter land-based livelihoods of some landowners, and possibly encourage land-use changes. Determining the spatial distribution of royalty payments from wind energy and estimating their total value are important first steps toward this objective. 


\section{Research Design}

\subsection{Study Region}

Our findings focus on Nolan and Taylor counties, a microcosm of a wider process that has made Texas the leading U.S. state in wind power. Nolan County (population $=14,700$ ) had a median household income of $\$ 37,500$ in 2009. Taylor County, where Abilene is the county seat, has 126,600 residents and a median household income of $\$ 40,400$ [6]. Rural landowners in both counties are at the eastern margins of the Permian Basin oil fields that developed in the 1920s and 1930s [25,26] and have some familiarity with energy payments and leases, mainly through family history and legal expertise, but no published data or analysis on oil and gas royalties in the study region exist.

Writing in the 1960s, Abilene journalist A.C. Greene ([25]; p. 149) wrote that wind was the "greatest natural resource in West Texas" but it was also the cause, or the excuse, for most of what is "uncomfortable, abominable, and harsh about the country," creating difficult conditions for ranching and farming. This steady wind would later become characterized more optimistically as favorable wind climatology, which, coupled with buoyant demand for electricity, little political opposition to wind-farm construction, and the country's lowest permitting requirements, made west Texas the North American leader for wind power. Nolan and Taylor counties, Texas (Figure 1), received large wind-power investments dating from the $150 \mathrm{MW}$ Trent Mesa site, built in 2001 by Enron's wind division. By 2009, the counties and adjacent areas had approximately $3000 \mathrm{MW}$ of installed wind power. Installation of new turbines in Nolan and Taylor counties slowed after 2009, but completion of new transmission lines around 2011 helped increase efficiencies and provide incentives for future development. Sweetwater, Nolan County's largest city, aims to brand itself as the center of wind-energy development by promoting trade shows, encouraging manufacturing related to wind power, and hosting a wind technician training program at a local community college (Figure 2).

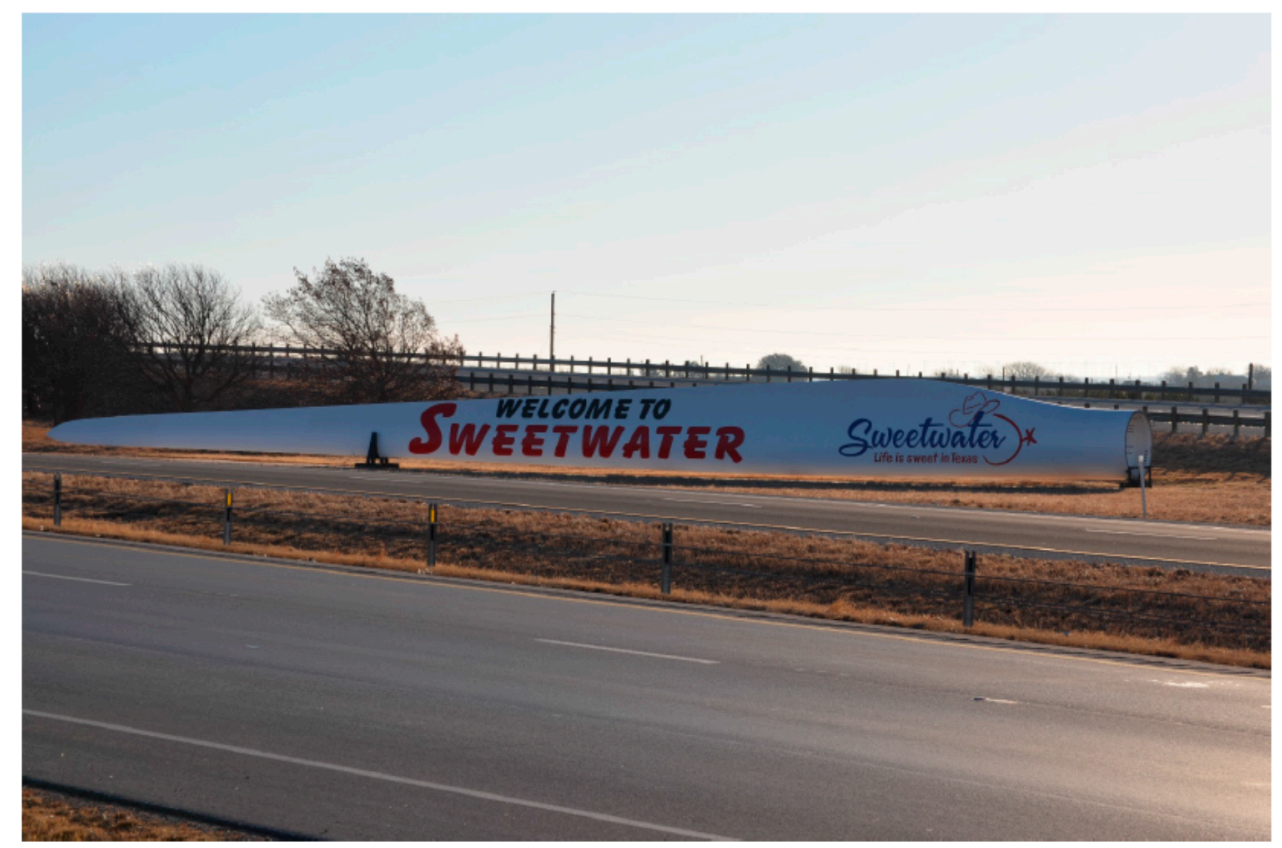

Figure 2. Wind turbine blade on Interstate 20 in Sweetwater suggesting the importance of wind energy to the city's identity and economy. 
The large and rapid investments in Texas wind power rely upon legislation promoting renewable energy standards and electricity market deregulation, authorized in 1999, just a few days after thengovernor George W. Bush declared his presidential candidacy. This statute resulted from Bush's desire to encourage wind-he told his top utility appointee to "go get smart on wind" ([7]; p. 121) in 1996 - and Enron chief Kenneth Lay's desire for a deregulated electricity market in Texas, which helped create conditions for Enron's construction of the Trent Mesa wind farm, signaling the start of the wind boom in Nolan and Taylor counties [7]. Complementing Bush's stance on renewables, Governor Rick Perry in 2005 authorized Competitive Renewable Energy Zones (CREZ), which linked rural regions with the greatest wind energy potential to Texas's growing urban areas through a $\$ 7$ billion transmission lines project capable of moving 18,500 MW [27]. These policies, combined with the federal Production Tax Credit (PTC) for renewable power generation [28] and the fact that Texas offers simple permitting of wind farms, requiring no public consultation or deliberation [23,29], created powerful economic and political incentives for wind farms.

However, the rapid growth of wind power in Texas inspired work critical of subsidies that were "compensating the market for unfavorable production locations" for wind power and had resulted in negative electricity prices ([30]; p. 30). Zarnikau ([31]; p. 3912) noted that wind-generated power cost three times more than producing electricity from natural gas, adding that wind power in the Electricity Reliability Council of Texas (ERCOT) produced "adverse impacts on system reliability." Recent reports indicate that the negative prices reported in 2011 and 2012 disappeared in 2013 and 2014 because of ERCOT's switch to a nodal system and increased transmission capacity through the CREZ program [27,32].

At the county level, property tax abatements and a "wind welcomer" posture by public officials and landowners attracted wind farm construction to the region $[33,34]$. Many political elites view tax abatements as essential to attracting firms to establish wind farms, although some officials are skeptical of the long-term benefits on public finances and infrastructure, suggesting an impending "day of reckoning" ([33]; p. 847). County officials justify tax abatements to constituents by arguing that the positive economic benefits - increased employment and economic activity - are greater than property tax forgone through abatements. Economic and political elites in the study area confirm the influence of county, state, and federal policies for attracting wind-energy firms, but they also note the importance of the under-utilized $345 \mathrm{kV}$ transmission line that carries power from gas-powered electricity generators in the Odessa and Midland through Nolan and Taylor counties to Dallas and Fort Worth [7].

Wind farms in the study region are sited exclusively on private properties. Firms establish land-use agreements with landowners, who usually pursue legal counsel as they seek to maximize their return on land leased for locating turbines, roads, substations, and maintenance facilities. During our previous research, key actors (large landowners, elected officials, business owners) told us that royalties were between $\$ 8000$ and $\$ 10,000$ per turbine per year [33]. Our earlier research led us to agree with Kahn [14] and Brown et al. [15], viewing the lease as a voluntary transaction for a land use that does not replace a more lucrative land use from the perspective of the land owner, and that the firm offering the contract prefers the site to other possible locations. The firm, of course, is influenced by incentives such as the federal PTC, which encourages rapid construction, and county-approved property tax abatements. 


\subsection{Data Sources}

Location of wind turbines was determined by the point locations for individual turbines obtained in 2010 from the Federal Aviation Agency (FAA), which we confirmed by checking data from the American Wind Energy Association and the Texas Public Utilities Commission (PUC). Wind turbines must be registered with the FAA because they are considered to be a flight obstruction; they must also be registered with the PUC because they provide electricity to ERCOT, the grid operator. In addition, we visually compared the mapped turbine locations against aerial photography because wind turbines are obvious features of the landscape. Each turbine has a known "nameplate" or potential output measured in megawatts. We omitted turbines outside Nolan and Taylor counties and a small number of turbines within the counties owned by state agencies. Assigning turbines to land parcels in our two-county study region yielded 1701 turbines with $\sim 2700$ MW capacity.

Next, GIS was used to assign wind turbines to land parcels to identify which landowners had wind turbines. We obtained geo-located parcel data accurate to the 2010 tax year from Nolan and Taylor County Appraisal Districts. We eliminated urban properties using a separate GIS layer identifying the boundaries of Sweetwater, Abilene, and other cities, which resulted in 17,500 total non-urban parcels in the two-county region. Next, we consolidated parcels according to tax address where parcels of land having the same tax address were combined into a single landholding. This procedure yielded 8370 landholdings with unique tax addresses. A spatial join was used to connect wind turbines to tax parcels, which yielded 241 private landholdings with turbines in the two-county area.

\subsection{Royalty Estimation}

To estimate royalties generated by wind turbines we employed electricity output, wholesale electricity price, and royalty rate. The Texas grid operator, ERCOT, reports electricity production by wind farm in 15-minute intervals. However, use of these electricity production data would not materially improve our royalty estimates because electricity sales prices and the royalty rates are confidential between landowner and wind farm operator. Neither of the latter figures is available in precise terms. Moreover, our goal was to determine the spatial distribution of estimated wind-energy royalties rather than establish a precise figure for royalties, which is not feasible because of the private nature of contracts governing transactions between wind-farm operator and landowner.

Instead of actual electricity output we employ capacity factor (CF), which is the efficiency of the wind turbine expressed as a percentage. $\mathrm{CF}$ is a product of engineering characteristics (hub height, rotor characteristics, scheduled maintenance, and sweep area of rotor blades, among others), wind characteristics (air density, wind velocity), transmission capacity, and electricity price. Ironically, CF data are made available in real time to wind farm technicians and managers, but are not reported transparently to the public; rather, CF data are notoriously shrouded in secrecy and often over-estimated by wind farm operators [35].

We considered various CF estimates appropriate to our study region. A Nolan County based group, the West Texas Wind Energy Consortium, commissioned a study of economic impacts of wind power that relied on a 35 percent CF estimate as the "accepted norm for Rolling Plains wind energy projects" ([36]; p. 7). The Texas Comptroller General [37] reported that the mean CF for Texas wind farms installed in 2004 and 2005 was 
39 percent, and cited at least one specific wind farm in the study region, Sweetwater-2, as having a CF between 35 to 40 percent. Bolinger and Wiser [28], based on data from 24 projects with installed capacity of $2275 \mathrm{MW}$, reported the U.S. average CF at between 33 and 35 percent for projects installed after 2003; however, Boccard [35] compared US installed capacity with output, arriving at 25.7 percent CF. A recent global estimate of wind power potential used a 20 percent CF [38]. The US average CF has remained at about 32 percent since 2000 [3].

In the Texas grid, transmission capacity lagged so far behind installed capacity that NextEra, a windfarm developer, built a 230-mile transmission line that boosted capacity factor of a west Texas wind farm from 20 to 29 percent. Lack of transmission capacity resulted in curtailment, which was most severe in 2009, immediately prior to construction of transmission lines through the CREZ [39]. The trend is for capacity factor to remain at approximately 32 percent in west Texas because new wind farms are being built in areas with relatively low wind quality [3]. Even with the construction of new transmission lines, wind farm managers in the region reported informally to the first author the occasional use of "economic curtailment," a situation in which the wind farm operator orders turbines into neutral position because the price of electricity does not compensate the cost of operating the turbine.

The second and third variables (wholesale electricity price and royalty rates) used to estimate royalties may have less variability but they are still cloaked in secrecy because landowners negotiate confidential contracts with wind-power firms. The wholesale electricity rate is estimated at approximately $\$ 40$ per $\mathrm{MWh}$ [36], although the figure of $\$ 35$ per MWh for Texas was reported recently [3], which is likely to include a Renewable Energy Credit (REC) [28]. It is known that several wind farms have long-term contracts with utilities, while others sell on the spot market, so any single figure is unlikely to match actual prices received. However, we consider our figures to be representative of the most likely prices that are used to compute royalties. Moreover, imprecision on electricity price does not influence the spatial distribution of estimated royalties.

Nolan County landowners receive a royalty, normally 4 percent or a minimum guaranteed payment, on the basis of the wholesale price of electricity produced [36,37]. Key actors in wind power in Nolan County noted that the Trent Mesa wind farm was on a 1 percent royalty rate while contracts signed in 2009 had reached 5 percent $[40,41]$. Landowners with turbines report differences between "good" and "bad" contracts, in that "bad" contracts have a low royalty and do not carry a guaranteed minimum payment, and often were negotiated during the early 2000s, the "wild west" period, according to one landowner. Ranchers who were among the earliest to host wind farms obtained royalty rates and payment terms inferior to landowners who signed contracts later. One key actor in wind power refers to discussion about contracts as "Dairy Queen talk," the sort of discussion among rural landowners over lunch specials at Dairy Queen, a fast-food chain popular among farmers and ranchers in rural Texas. The reference to "Dairy Queen talk" suggests that variability exists among royalty rates, but that is not possible to determine actual rates without gaining trust among landowners. Therefore, we rely on the 4 percent royalty rate in our calculations.

To estimate royalty rate (per turbine per year) from wind power we created an equation relating MW capacity $(\mathrm{CF})$, wholesale electricity price, and royalty rate:

Estimated royalty $($ per turbine per year $)=\mathrm{CF}(\mathrm{MW}) *$ Price $(\mathrm{MW} / \mathrm{h}) *$ hours/year * royalty rate 
Using Equation (1) we computed a low royalty estimate $(\mathrm{CF}=25 \%$, wholesale electricity price $=\$ 35 / \mathrm{MWh}$, and royalty rate $=4 \%)$, a high estimate $(\mathrm{CF}=35 \%$, wholesale electricity price $=\$ 45 / \mathrm{MWh}$, and royalty rate $=4 \%$ ). We calculated a mean royalty estimate per turbine from high and low estimates, then we applied this to the entire wind farm and aggregated to the landholding on which the turbines were located. Table 1 reports wind farms in the study region, their estimated electrical production and royalty rate per turbine per year. For example, the 67 turbines at Buffalo Gap would produce $\sim 264,000 \mathrm{MWh}$ per year at capacity factor of 25 percent, yielding gross revenues of $\$ 9.2$ million at $\$ 35$ per MWh. But at 35 percent capacity factor, and $\$ 45$ per MWh, gross revenues would increase to $\$ 16.9$ million per year. A fixed royalty of 4 percent would yield a mean, between high and low estimates, of $\$ 7726$ per turbine per year (Table 1).

We used distance as a proxy for absentee ownership and land rental. Specifically, we determined driving distance from the situs (property) address, defined as the latitudinal and longitudinal location of the centroid of a single land parcel or aggregated parcels, to the tax appraisal (mailing) address. We assumed that the address listed for mailing the property tax statement is the same as the residential address, although it is possible that an attorney or financial advisor receives the tax correspondence for some landowners. The latitude and longitude coordinates of the parcel were entered into a Google Maps directions form, yielding turn-by-turn driving directions. To determine the driving distance for all 241 landowners with turbines, we wrote a C\# script to query Google Maps for driving distance and time between two points excluding the turn-by-turn instructions. These distances were then added as landowner attributes.

Table 1. Summary of wind farms, capacity, and estimated royalty.

\begin{tabular}{ccccc}
\hline Wind Farm Name & $\begin{array}{c}\text { No. } \\
\text { Turbines }\end{array}$ & $\begin{array}{c}\text { MW per } \\
\text { Turbine }\end{array}$ & $\begin{array}{c}\text { Total } \\
\text { MW }\end{array}$ & $\begin{array}{c}\text { Estimated Royalty per } \\
\text { Turbine per Year (\$) }\end{array}$ \\
\hline Buffalo Gap & 67 & 1.8 & 120.6 & 7726 \\
Buffalo Gap 3 & 73 & 2.3 & 167.9 & 9873 \\
Buffalo Gap II & 139 & 1.5 & 208.5 & 6439 \\
Callahan Divide & 76 & 1.5 & 114 & 6439 \\
Champion (Roscoe II) & 54 & 2.3 & 124.2 & 9873 \\
Horse Hollow II & 125 & 2.3 & 287.5 & 9873 \\
Horse Hollow & 292 & 1.5 & 438 & 6439 \\
Inandale (Roscoe IV) & 143 & 1.0 & 143 & 4292 \\
Roscoe & 100 & 1.0 & 100 & 4292 \\
South Trent Mesa & 43 & 2.3 & 98.9 & 9873 \\
Sweetwater & 171 & 1.5 & 257 & 6439 \\
Sweetwater 4a & 124 & 1.0 & 124 & 4292 \\
Sweetwater 4b & 46 & 2.3 & 105.8 & 9873 \\
Sweetwater 5 & 34 & 2.3 & 78.2 & 6873 \\
Trent Mesa & 101 & 1.5 & 151.5 & 6439 \\
Turkey Track & 113 & 1.5 & 169.5 & \\
Total & 1701 & & 2688.1 & \\
\hline
\end{tabular}

We interpret results based on our knowledge of the study region, obtained through key informant interviews conducted in 2010 and subsequent annual two-day field trips with undergraduate students 
enrolled in a "Geography of Energy" course taught by the first author. During these field trips, which included wind farm site visits and panel discussions, students inquired about royalties. Answers from key informant interviews and panelists, who included county commissioners and landowners, helped us determine the values for formula (1) and interpret results.

\section{Results and Discussion}

Total royalties for the two-county study region were estimated at $\sim \$ 11.5$ million per year, slightly less than the $\$ 12.264$ million per year estimate of royalties accrued from $2500 \mathrm{MW}$ installed capacity, which assumed a 35 percent $\mathrm{CF}, \$ 40 / \mathrm{MWh}$ wholesale electricity price, and 4 percent royalty rate [36]. The mean annual royalty received per landowner per year was estimated at $\$ 47,879$ (for 7 turbines on 274 hectares). The median annual royalty was $\$ 25,756$ (for 4 turbines on 129 hectares), less than median household income in either county. Mean driving time from landholding to tax address was slightly more than 2 hours, although the median driving time was 38 minutes. The mean landholding for the sample was 274 hectares (Table 2).

Only 241 landowners out of $\sim 8370$ rural landowners in the study region have wind turbines on their land. This small fraction, less than 3 percent, of rural landowners shows how pre-existing land-tenure patterns, the "property advantage," enabled some landowners to obtain royalties from wind farms because of factors relating to size or relative location of their land before the development of wind farms. A similar low fraction of participation in energy assets has been reported for shale gas underneath Denton, Texas, where 2.4 percent of subsurface mineral (gas) value was owned by family trusts and individuals with Denton tax addresses [9].

Table 2. Summary statistics for estimated royalty, distance between landholding and tax address, landholding area, and number of turbines per landholding $(n=241)$.

\begin{tabular}{ccccc}
\hline & $\begin{array}{c}\text { No. } \\
\text { Turbines }\end{array}$ & $\begin{array}{c}\text { Estimated Royalty } \\
\text { Per Landholding (\$) }\end{array}$ & $\begin{array}{c}\text { Driving Time (minutes) } \\
\text { to Tax Address }\end{array}$ & $\begin{array}{c}\text { Landholding Area } \\
\text { (hectares) }\end{array}$ \\
\hline Total & 1701 & $11,538,769$ & 33,198 & 66,117 \\
Mean & 7 & 47,879 & 138 & 274 \\
Median & 4 & 25,756 & 38 & 129 \\
Mode & 2 & 29,619 & 21 & 65 \\
SD & 11 & 70,850 & 260 & 494 \\
\hline
\end{tabular}

The total area of the 8370 landholdings was 452,800 hectares (mean $=54.1$ hectares), and median size of 2.4 hectares; this compares to the $\sim 66,000$ hectares of the 241 landholdings that have turbines located on their land. Some landowners without turbines may have refused to sign contracts with wind-power developers, but many others may have had land parcels too small for siting turbines, or land with unsuitable topography, low wind potential, or poor road access.

Distribution of royalties by quintile is shown in Table 3. The top quintile concentrates 60 percent of royalties, with a mean of $\$ 146,189$ (median $=\$ 100,444)$ per landholding per year. This group $(n=48)$ has a mean landholding area of 842 hectares. By contrast, the fifth quintile captures less than 4 percent of total royalties $($ mean $=\$ 7656$, median $=\$ 8584)$, with 1.3 turbines per landholding on average. 
Table 3. Landholdings with turbines divided into quintiles for number of turbines and estimated royalty per landholding per year.

\begin{tabular}{cccc}
\hline Quintile and Metric & No. Turbines & $\begin{array}{c}\text { Royalty per Landholding } \\
\text { per Year (\$) }\end{array}$ & Area per Landholding (ha) \\
\hline Q1 Total $(\mathrm{n}=48)$ & $1020(60.8 \%)$ & $7,017,091(60.0 \%)$ & $40,425(61.1 \%)$ \\
Mean & 21.3 & 146,189 & 842.2 \\
Median & 14 & 100,444 & 497.5 \\
Standard Dev. & 17.9 & 111,288 & 883.9 \\
\hline Q2 Total $(\mathrm{n}=48)$ & $328(18.5 \%)$ & $2,129,078(19.3 \%)$ & $11,442(17.3 \%)$ \\
Mean & 6.8 & 44,356 & 238.4 \\
Median & 6 & 39,492 & 211.5 \\
Standard Dev. & 1.7 & 10,932 & 152.4 \\
\hline Q3 Total $(\mathrm{n}=48)$ & $173(10.8 \%)$ & $1,249,539(10.2 \%)$ & $5334(8.1 \%)$ \\
Mean & 3.6 & 26,032 & 111.1 \\
Median & 4 & 27,473 & 86.5 \\
Standard Dev. & 0.5 & 4134 & 87.0 \\
\hline Q4 Total $(\mathrm{n}=48)$ & $117(6.7 \%)$ & $767,913(6.9 \%)$ & $5307(8.0 \%)$ \\
Mean & 2.4 & 15,998 & 110.6 \\
Median & 2 & 17,168 & 70.0 \\
Standard Dev. & 0.5 & 3340 & 84.5 \\
\hline Q5 Total $(\mathrm{n}=49)$ & $63(3.3 \%)$ & $375,148(3.7 \%)$ & $3609(5.5 \%)$ \\
Mean & 1.3 & 7656 & 73.7 \\
Median & 1 & 8584 & 65.0 \\
Standard Dev. & 0.5 & 2067 & 60.6 \\
\hline
\end{tabular}

Regarding the spatial distribution of royalties per landholding, there is a clear divide between relatively large ranches (used for livestock grazing and hunting leases) south of Sweetwater and small farms, mainly growing cotton without irrigation, near Roscoe (Figure 3). We found significant differences $(p<0.05)$ for royalty per landholding per year by landholding area (Table 4). Roscoe landholdings had a mean annual royalty of $\$ 19,310$, while Sweetwater landholdings had a mean royalty of $\$ 63,000$ per year.

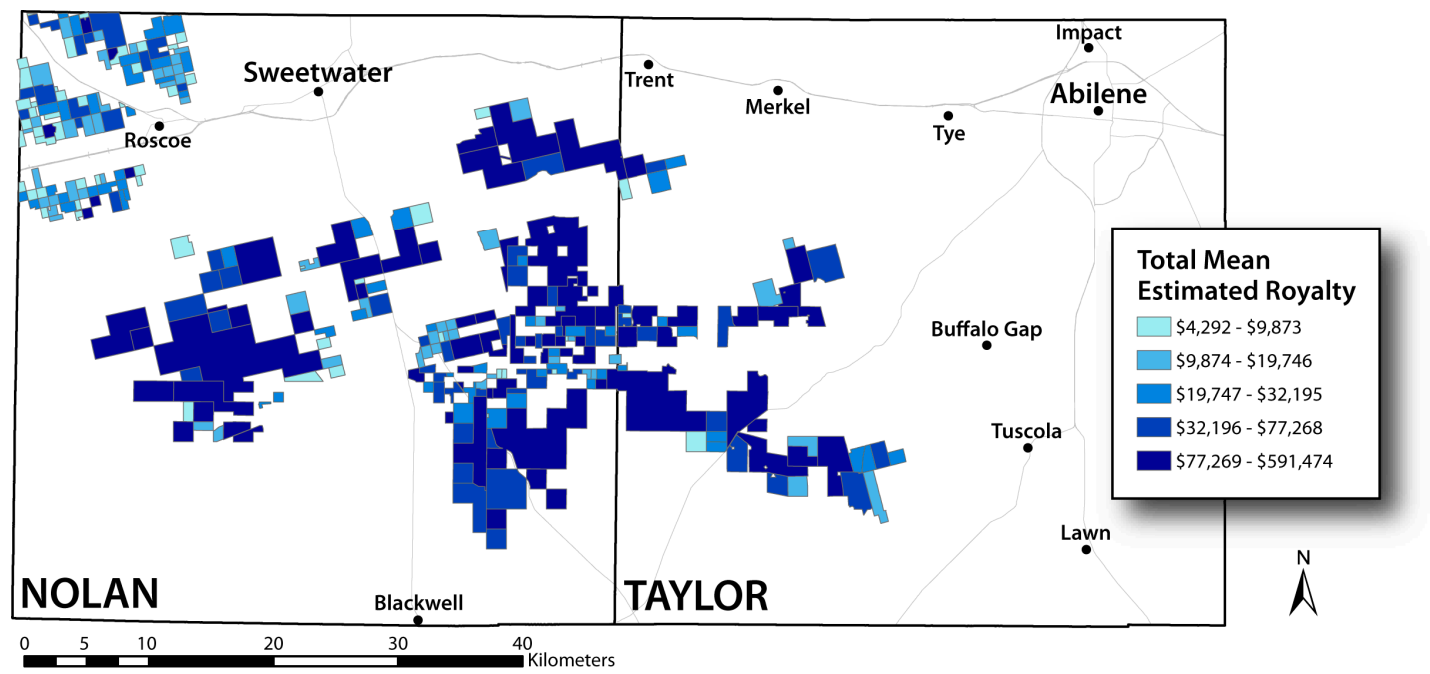

Figure 3. Spatial distribution of estimated royalties per landholder per year in Nolan and Taylor Counties. 
The distribution of Roscoe royalties may be different than our estimates indicate. Around 2005, an entrepreneurial leader organized farmers as a "unitized" group of 120 landowners covering 13,000 hectares [41]. Roscoe's many small landholdings, mainly devoted to rainfed cotton, were considered unattractive to wind developers. Unitization, a well-established practice in oil and gas production whereby small fields are grouped into one, and royalties are divided among members [42], helped make the region attractive to firms because they would negotiate one contract with a group, rather than with many small owners of rights. Royalties to all participants in the "unitized" group would include landowners without turbines, perhaps with land parcels too small or not well suited to the designs of the wind-farm developer, therefore slightly increasing the number of rural landowners receiving royalty payments.

Table 4. Descriptive statistics for landholdings with turbines in the Roscoe and Sweetwater areas. Royalty column refers to estimated royalty per landholding per year.

\begin{tabular}{ccccccc}
\hline & \multicolumn{3}{c}{ Roscoe $(\mathbf{n}=\mathbf{8 5})$} & \multicolumn{3}{c}{ Sweetwater $(\mathbf{n}=\mathbf{1 5 6})$} \\
\cline { 2 - 7 } & No. Turbines & Royalty & Hectares & No. Turbines & Royalty & Hectares \\
\hline Mean & 3.6 & 19,310 & 115.6 & 8.9 & 63,307 & 361.3 \\
Median & 3.0 & 12,876 & 65.0 & 4.0 & 32,195 & 182.5 \\
Mode & 2.0 & 8584 & 65.0 & 3.0 & 29,619 & 259.0 \\
SD & 3.1 & 15,857 & 97.6 & 12.9 & 83,351 & 593.2 \\
\hline
\end{tabular}

We also determined the driving distance from landholding to tax address (Table 5) as a proxy for land rental and absentee ownership. We separated landowners with royalties into two groups, using 45 minutes driving time as a threshold, but found no significant difference in estimated royalty. Considering the tax address, we found that approximately 60 percent of total royalties accrued to landowners residing within Nolan and Taylor counties. It is possible that some of these landowners rent their land to ranch operators, but it is also possible that most landowners residing in Nolan and Taylor counties are the operators of their farm or ranch land. Around 30 percent of total royalties went to landowners residing elsewhere in Texas, and 7 percent of total royalties accrued to landowners residing outside Texas.

Table 5. Landholdings, turbines and estimated royalty per landholding per year according to location of tax address.

\begin{tabular}{cccc}
\hline Tax Address & No. Landholdings & No. Turbines & Royalty (\$) \\
\hline Nolan County & $105(43.6 \%)$ & $739(43.4 \%)$ & $4,867,684(42.2 \%)$ \\
Taylor County & $42(17.4 \%)$ & $312(18.3 \%)$ & $2,219,266(19.2 \%)$ \\
Other Texas & $79(32.8 \%)$ & $538(31.6 \%)$ & $3,652,962(31.7 \%)$ \\
Other U.S. & $15(6.2 \%)$ & $112(6.6 \%)$ & $798,857(6.9 \%)$ \\
Total & 241 & 1701 & $11,538,769$ \\
\hline
\end{tabular}

Estimating livelihood and land-use impacts is not possible with our findings, but theoretical claims and qualitative evidence offer several suggestions. First, Weber et al. [8] rely on a combination of life-cycle and behavioral frameworks [43] to argue that energy payments, such as wind royalties, may be consumed, saved, or invested. They assume that energy amenities or disamenities will affect land value, and, therefore, household wealth. Wind turbines are considered amenities and therefore add to 
land value. They argue that increased land value accounts for approximately 75 percent of total estimated private wealth from energy royalties. By comparison, consumption and farm investment are low, approximately 4.2 cents of marginal consumption for every dollar of energy payment.

Qualitative evidence from fieldwork offers other suggestions. Landholders offer many answers - except specific ones regarding actual investments - when approached on the topic of royalties. Previous work has suggested the existence of a particular moral economy in which wind power keeps farms and ranches in families, while landowners remain environmentally skeptical [33,34]. "Pay my notes (farm debt)" was the response of a cotton farmer in Roscoe when asked what he did with his wind-power royalties. For this farmer, landowners with turbines on cotton fields lost between 3 and 5 percent of farm area to pad site and access roads, making turbines attractive [41]. Similarly, a rancher outside Sweetwater joked that royalties allowed him to "maintain my hobby," by which he meant ranching in difficult climatic times. Farming or ranching is a "pretty tough gig" in the Nolan-Taylor region. Royalties help "pay bills and put kids through college." Landowners with turbines indicated that royalties helped families maintain their land, which had been in precarious state because of the declining cattle economy and lack of rainfall. But wind might also be just another type of energy income. Wind, according to one landowner, was "strictly money," echoing findings reported elsewhere [34].

It is not known whether life-cycle and behavioral frameworks [43] should be modified to particular conditions of west Texas. Perhaps the only published observation is that of Greene ([25]; pp. 24-25), who argued that west Texas landowners viewed income from cattle as more noble than income from oil, recounting the story of a rancher who "hated the idea that none of this new wealth [from oil] was his doing, as his cattle and his land deals had been." Greene also drew contrasts between the region's Christian morality ("God is the biggest industry in west Texas") and the "sinful humanity" and oilmen (a "villain, seen as a creature of lawyers and bankers") attracted by oil to west Texas ([25]; pp. 130, 163). It is unclear how broadly these assertions, if accurate, apply to current landowners, because as one landowner told us, "you do not gripe about the money that is coming in from oil wells, and you shouldn't be concerned about money coming in from the wind farms" ([34]; p. 859). It is also unknown whether a form of energy payment that is held in contempt, as Greene [25] suggested, is any different from wind royalties, which are viewed positively, in terms of consumption, savings, or investment. Whether households use royalties produced in this context any differently than models suggest is an open empirical question with implications for the vast areas of wind-power development.

Royalties from wind-power production accrue to hundreds of landowners in a vast area of central North America that hosts much of U.S. wind-power capacity. This area is spatially coincident with high reported social acceptance of wind power. The "property advantage" describes unequal distribution in royalties predicated upon land-tenure inequalities established before wind-power development. Because of their "property advantage," and without "unitization," some landowners will benefit significantly more than other landowners. The vast majority of people in rural areas who do not own land are excluded from royalties, but may benefit from wind power in other ways [14-16]. Future studies of social acceptance or rejection of wind farms should test for royalty effects, especially in rural areas where drought or poor commodity prices adversely affect farming and ranching, paying attention to particular moral economies that may not conform to models.

We also identify a "royalty paradox," the situation in which estimated royalties accrue to only a small fraction of rural landowners, even though support for wind power apparently extends into the general 
population, far broader than the small sub-population of landowners with turbines. We do not know how large payments to a small number of landowners translate into apparent high social acceptance. But it is likely that the landowners who benefit the most from royalties are prominent spokespersons for the wind economy, occupying key positions in organizations such as local school boards and other local civic groups that help influence opinion. They may be the "wind welcomers" previously described [33]. It is beyond the scope of this study to understand the behavior of local elites, but it is likely that landowners with royalties influence local discourse and opinion through varied means.

The influence of royalties on livelihoods and, by extension, land-change patterns, is not known. However, understanding the spatial distribution of royalties is an important starting point. A next step is to consider how landowners treat wind royalties, perhaps informed by a particular moral economy, and whether actual behaviors conform to the more well studied government payments that are independent of farm production decision making [43]. Even if a moral economy for wind royalties does not exist, it is possible that landowners at the lower quintiles treat royalties no differently than other sources of farm income-perhaps they just "pay notes," as one farmer told us. But at the upper quintiles, landowners may take different decisions with their royalty income, using royalties to fund capital expenses, invest in education of their children, or support their "hobby." Behavioral models may prove useful to offer estimates based on amount of royalty income and existing land cover (cotton or scrub vegetation), for example. An increase in land value among landholdings with energy payments, which Weber et al. [8] predict, may have numerous direct and indirect consequences that future research may determine. Certainly, the property value effect of wind power as an amenity may become apparent in property tax datasets and will figure highly in household wealth.

Our estimates of royalties are conservative because they do not include land leases for roads or maintenance facilities; nor does our estimated royalty include the signing bonus, which varies substantially among firms and landowner contracts. In addition, actual royalties could be higher because nameplate capacity may have been increased through software and hardware upgrades, either under manufacturer warranty or in the after-market period beyond warranty.

We cannot validate our royalty estimates because royalty rates are confidential between wind farm and landowner, and because wholesale electricity prices may vary considerably depending on contract terms between wind farms and utility. Future research aiming to model wholesale electricity price, coupled with analysis of actual electricity output per wind farm, could improve the accuracy of our estimates, but those estimates would still not have accurate estimates of the royalty rate.

The flow of wind-power royalties is contingent, of course, on the price of wholesale electricity, the output of turbines, and contract terms. Sales of land with wind turbines may slow, as farmers are reluctant to part with their royalty payments; however, some observers report the development of contract terms that allow land sellers to retain their royalties after selling the land. It is not yet known how landowners will respond when contracts approach the end of the projected lifetime of wind turbines, and whether renegotiation opportunities may exist, especially as wind farms change ownership.

At a county level, future research could compare royalties that accrue privately with the cost of subsidies, in terms of property tax abatements, that are borne by the public in terms of property taxes assessed overall. County subsidies in the form of tax abatements may lower overall property tax rates, and help county officials politically, but they also encourage the flow of considerable benefits to a tiny minority of landowners. 
Our findings indicate some challenges in conducting research aiming to link energy with land change and livelihoods in North America. The development of renewable energy in central North America, from Texas to Minnesota, is relatively recent, and while apparent impacts on land cover from the construction of wind turbines are plainly visible, possible effects on land use and landowner livelihoods are far more difficult to discern. The fact that wind power is located almost entirely on private landholdings means that landowners are "visible" in terms of tax addresses, but potentially high non-response bias will confront researchers aiming to determine the use of royalties through mail-out or online surveys. Qualitative and ethnographic methods may reveal important insights into the ways that renewable energy influences land uses through royalties, but require high levels of trust and long periods of field work.

\section{Conclusions}

Estimated royalties from wind power are unequally distributed among a small fraction of rural landowners who use the income in unknown ways to support their livelihoods. Landowners may try to overcome initial land inequality though cooperative agreements, known as "unitization," borrowed from oil and gas institutions. Royalties may help explain reported high support for wind power in the rural U.S., but livelihood and land-change outcomes of royalties are not yet known. We identified the "property advantage," the land-tenure patterns established before wind-power development that determine the unequal distribution of royalties. The "royalty paradox" refers to how royalty payments to a small number of landowners help produce high social acceptance, probably through the discursive and political actions of this small group of landowners. Future research should determine behavioral aspects of wind-royalty income and impacts on property value, which could influence land use and land cover.

\section{Acknowledgments}

We thank the Wind Initiative at Texas Christian University for supplying datasets and funding earlier research, and Nicole Persons for assisting in data collection in early phases of the research. Comments by Jackie Vadjunec, Claudia Radel, and anonymous reviewers improved earlier drafts.

\section{Author Contributions}

Christian Brannstrom designed the research, conducted research, analyzed the data, and wrote the paper; Mary Tilton conducted research; Andrew Klein conducted research and analyzed the data; Wendy Jepson designed the research and conducted research.

\section{Conflicts of Interest}

The authors declare no conflict of interest. The founding sponsors had no role in the design of the study; in the collection, analyses, or interpretation of data; in the writing of the manuscript, and in the decision to publish the results. 


\section{References and Notes}

1. Brannstrom, C.; Vadjunec, J. Notes for avoiding a missed opportunity in sustainability science: Integrating land change science and political ecology. In Land Change Science, Political Ecology, and Sustainability: Synergies and Divergences; Brannstrom, C., Vadjunec, J., Eds.; Earthscan from Routledge: Abingdon, UK, 2013; pp 1-23.

2. Public Land and Wind Energy. Available online: http://www.awea.org/Issues/ Content.aspx?ItemNumber $=858$ (accessed on 25 July 2014).

3. Wiser, R.; Bolinger, M. 2012 Wind Technologies Market Report; U.S. Department of Energy: Washington, DC, USA, 2013.

4. Wind Generates More than $10 \%$ of Texas Electricity in 2014. Available online: http://www.eia.gov/todayinenergy/detail.cfm?id=20051 (accessed on 7 June 2015).

5. Swofford, J.; Slattery, M. Public attitudes of wind energy in Texas: Local communities in close proximity to wind farms and their effect on decision-making. Energy Policy 2010, 38, 2508-2519.

6. Slattery, M.C.; Johnson, B.L.; Swofford, J.A.; Pasqualetti, M.J. The predominance of economic development in the support for large-scale wind farms in the U.S. Great Plains. Renew. Sustain. Energy Rev. 2012, 16, 3690-3701.

7. Galbraith, K.; Price, A. The Great Texas Wind Rush: How George Bush, Ann Richards, and a Bunch of Tinkerers Helped the Oil State Win the Race to Wind Power; University of Texas Press: Austin, TX, USA, 2013.

8. Weber, J.G.; Brown, J.P.; Pender, J. Rural Wealth Creation and Emerging Energy Industries: Lease and Royalty Payments to Farm Households and Businesses; Federal Reserve Bank of Kansas City: Kansas City, MO, USA, 2013.

9. Fry, M.; Briggle, A.; Kincaid, C. Fracking and environmental (in) justice in a Texas City. Ecol. Econ. 2015, 117, 97-107.

10. Sowers, J. Fields of opportunity wind machines return to the plains. Gt. Plains Q. 2006, 26, 99-112.

11. Walker, C.; Baxter, J.; Ouellette, D. Beyond rhetoric to understand determinants of wind turbine support and conflict in two Ontario, Canada communities. Environ. Plan. A 2013, 46, 730-745.

12. Abbott, J.A. The localized and scaled discourse of conservation for wind power in Kittitas County, Washington. Soc. Nat. Resour. 2010, 23, 969-985.

13. Mulvaney, K.K.; Woodson, P.; Prokopy, L.S. A tale of three counties: Understanding wind development in the rural midwestern United States. Energy Policy 2013, 56, 322-330.

14. Kahn, M.E. Local non-market quality of life dynamics in new wind farm communities. Energy Policy 2013, 59, 800-807.

15. Brown, J.P.; Pender, J.; Wiser, R.; Lantz, E.; Hoen, B. Ex post analysis of economic impacts from wind power development in U.S. counties. Energy Econ. 2012, 34, 1743-1754.

16. Slattery, M.; Lantz, E.; Johnson, B.L. State and local impacts from wind energy projects: Texas case study. Energy Policy 2011, 39, 7930-7940.

17. Lantz, E.; Tegen, S. Variables affecting economic development of wind energy. Presented at WINDPOWER 2008, Houston, TX, USA, 1-4 June 2008.

18. Greene, J.S.; Geisken, M. Socioeconomic impacts of wind farm development: A case study of Weatherford, Oklahoma. Energy Sustain. Soc. 2013, doi:10.1186/2192-0567-3-2. 
19. BBC News. The world's largest wind farms. BBC News 25 November 2010.

20. Shlachter, B. Rancher's windfall. Ft. Worth Star-Telegram 29 January 2006.

21. Baxter, J.; Morzaria, R.; Hirsch, R. A case-control study of support/opposition to wind turbines: Perceptions of health risk, economic benefits, and community conflict. Energy Policy 2013, 61, 931-943.

22. Warren, C.R.; McFayden, M. Does community ownership affect public attitudes to wind energy? A case study from south-west Scotland. Land Use Policy 2010, 27, 204-213.

23. Bohn, C.; Lant, C. Welcoming the wind? Determinants of wind power development among U.S. States. Prof. Geogr. 2009, 61, 87-100.

24. Pasqualetti, M.J. Opposing wind energy landscapes: A search for common cause. Ann. Assoc. Am. Geogr. 2011, 101, 907-917.

25. Greene, A.C. A Personal Country; Texas A\&M University Press: College Station, TX, USA, 1979 (1969).

26. Moore, R.R. West Texas after the Discovery of Oil: A Modern Frontier; Jenkins Publishing and Pemberton Press: Austin, TX, USA, 1971.

27. Fewer Wind Curtailments and Negative Power Prices Seen in Texas after Major Grid Expansion. Available online: http://www.eia.gov/todayinenergy/detail.cfm?id=16831 (accessed on 7 June 2015).

28. Bolinger, M.; Wiser, R. Wind power price trends in the United States: Struggling to remain competitive in the face of strong growth. Energy Policy 2009, 37, 1061-1071.

29. Parker, B.D. Capturing the Wind: The Challenges of a New Energy Source in Texas; House Research Organization: Austin, TX, USA, 2008.

30. Baldick, R. Wind and energy markets: A case study of Texas. IEEE Syst. J. 2012, 6, 27-34.

31. Zarnikau, J. Successful renewable energy development in a competitive electricity market: A Texas case study. Energy Policy 2011, 39, 3906-3913.

32. Tao, H.Y.S.; Srivastava, A.K.; Pineda, R.L.; Mandal, P. Wind power generation impact on electricity price in ERCOT. In Proceedings of the IEEE Power and Energy Society General Meeting, San Diego, CA, USA, 22-26 July 2012; pp. 1-7.

33. Brannstrom, C.; Jepson, W.; Persons, N. Social perspectives on wind-power development in west Texas. Ann. Assoc. Am. Geogr. 2011, 101, 839-851.

34. Jepson, W.; Brannstrom, C.; Persons, N. "We don't take the pledge": Environmentality and environmental skepticism at the epicenter of US wind energy development. Geoforum 2012, 43, 851-863.

35. Boccard, N. Capacity factor of wind power realized values vs. estimates. Energy Policy 2009, 37, 2679-2688.

36. New Amsterdam Wind Source. Nolan County: Case study of wind energy economic impacts in Texas. 2008. Available online: http:/www.moakcasey.com/articles/viewarticledoc.aspx/ Nolan\%20County\%20Case\%20Study.pdf?AID=168\&DID=288 (accessed on 2 March 2009).

37. Combs, S. The Energy Report; Texas Comptroller of Public Accounts: Austin, TX, USA, 2008.

38. Lu, X.; McElroy, M.B.; Kiviluoma, J. Global potential for wind-generated electricity. Proc. Natl. Acad. Sci. USA 2009, 109, 10933-10938.

39. Wiser, R.; Bolinger, M. 2008 Wind Technologies Market Report; Department of Energy: Washington, DC, USA, 2009. 
40. Confidential interview with respondent 17, 20 May 2009.

41. Confidential interview with respondent 25, 2 October 2010.

42. Weaver, J.L. Unitization of Oil and Gas Fields in Texas: A Study of Legislative, Administrative, and Judicial Policies. Resources for the Future: Washington, DC, USA, 1986.

43. Whitaker, J.B. The varying impacts of agricultural support programs on U.S. farm household consumption. Am. J. Agric. Econ. 2009, 91, 569-580.

(C) 2015 by the authors; licensee MDPI, Basel, Switzerland. This article is an open access article distributed under the terms and conditions of the Creative Commons Attribution license (http://creativecommons.org/licenses/by/4.0/). 